\title{
Agriculture in Southeast Asia: Rethinking contemporary issues using sociology of gender and family
}

\author{
Veronica L. Gregorio ${ }^{1^{*}}$ \\ ${ }^{1}$ Department of Sociology, National University of Singapore, Singapore \\ * Corresponding author \\ E-mail address: v.gregorio@u.nus.edu \\ DOI: https://doi.org/10.21107/sml.v4i1.9520
}

\begin{tabular}{|c|c|}
\hline Article Info & Abstract \\
\hline $\begin{array}{l}\text { Keywords: } \\
\text { agriculture } \\
\text { ASEAN4 } \\
\text { development } \\
\text { family } \\
\text { gender } \\
\text { Southeast Asia }\end{array}$ & $\begin{array}{l}\text { This article provides an overview of how agricultural development and } \\
\text { structural changes affects women in Southeast Asia. By employing critical } \\
\text { literature review, it enumerates how global agriculture can be characterized } \\
\text { as under a modern capitalist system of production by looking at trends on } \\
\text { labor and distress migration, scientific and technological innovations (STIs), } \\
\text { and intensification of non-traditional agricultural exports (NTAEs). Following } \\
\text { this, it makes a case for Southeast Asia's ASEAN4 (Philippines, Thailand, } \\
\text { Indonesia, Malaysia) explaining how the conditions of women farmers } \\
\text { should be explored further, not just in a developmental lens but in sociology } \\
\text { of gender and family approaches. The article then discusses regional works } \\
\text { about masculinization and feminization, engendered resistance, agency } \\
\text { and multiplicity of identities, and intra-household relations. Towards the } \\
\text { conclusion, it emphasizes points on challenging the terms "farmer" and } \\
\text { "feminization," reconsidering regional contexts, examining the family's } \\
\text { intra-household relationship, scrutinizing the position of the local state, and } \\
\text { ways to move forward. }\end{array}$ \\
\hline
\end{tabular}

Citation suggestion:

Gregorio, V. L. (2021). Agriculture in Southeast Asia: Rethinking contemporary issues using sociology of gender and family. Simulacra, 4(1), 15-28. https://doi.org/10.21107/sml.v4i1.9520

Received 11 January 2021; Received in revised form 5 February 2021; Accepted 18 February 2021; Published online 25 June 2021. 


\section{Introduction}

The study of gender and development can be rooted from the classic work of Boserup (1970), Women's Role in Economic Development, which calls for development institutions and government bodies to see the varying impacts of modernization to men and women. Research and policyoriented programs for women's rights and gender equality were implemented under the frameworks of Women in Development (WID), which later on became Women and Development (WAD), and now called Gender and Development (GAD) (Chauhan, 2014; Rathgeber, 1990).

Literature on the history of gender and development show that WID sprang alongside the growing women's movement carrying liberal feminist politics that demanded for their integration in the economy. It transformed to the WAD approach in order to study the relationship between development processes and women from poor regions. These frameworks gave way to GAD in the 1980s, which highlights how development process needs to consider the intersections of genders (both men and women) and class differences. This approach also stresses women's agency in terms of having political voices. One of the most visible results of the WID, WAD, and GAD frameworks are the series of UN Decade of Women conferences. The first one was held in Mexico City in 1975, followed by Copenhagen in 1980, Nairobi in 1985, and Beijing in 1995. The common themes discussed in these conferences are equal pay for men and women, elimination of violence against women, and strengthening of women's roles in the various sectors, one of which is agriculture (Benería, Berik, \& Floro, 2016; Momsen \& Kinnaird, 1993; Rathgeber, 1990).

The field of gender and agriculture covers the changing patterns in agricultural production and how gender plays a role in its development and vice-versa. Furthermore, it also incorporates land input and outputrelated decision-making processes within farming families. It is therefore crucial for scholars to understand how women are located in a sector where the label "farmer" is generally seen and interpreted as equivalent to man (Illo \& Marquez, 1994; Shortall, 1999) and where feminization is said to be continuously happening due to industrialization and structural economic changes (Boserup, 1970; Lastarria-Cornhiel, 2008). While the said field is present in sociology, most of the current works are produced by research and development institutions (Bhandari, 2017) and there was a decline in conducting studies that touch on rural-based gender and family issues compared to the 1970s (Thompson, 2015).

The rest of the sections show how empirical evidences from Africa, Latin America, and Asia speak to each other. Despite this, it is contended by Akter et al. (2017) that particularly within Asian literature, there are limited studies in Southeast Asia. This is explicitly shown in Momsen \& Kinnaird's (1993) Different Place, Different Voice: Gender and Development in Africa, Asia, and Latin America and Quisumbing, Meinzen-Dick, Raney, \& Croppenstedt's (2014) report "Gender in Agriculture: Closing the Knowledge Gap." The former is composed of twenty-one (21) chapters where $34 \%$ are from South Asia, $25 \%$ are from Africa, $25 \%$ are also from Latin America, $6 \%$ is from Oceania, and only $10 \%$ are from Southeast Asia, which are both focused in Malaysia. For the latter, 59\% of the cases are from Africa, 22\% from South Asia, $13 \%$ from other regions, and only $6 \%$ are from Southeast Asia. This suggests that women farmers in the Southeast Asia are not well included in global reports and studies despite the fact that the region produces 
$25 \%$ of the world's agricultural commodities (ASEAN Trade Statistics Database, 2015).

\section{Method}

Comparison of peer-reviewed literature (articles and books) from 1991 to 2016 was conducted and a critical examination of its chronological development was incorporated in the next two main sections of this paper. The literature collection was done by crossreferencing major journals and earlier books cited. By employing critical literature review, this paper highlights shared characteristics and the conditions of women farmers in the world and further focusing on Southeast Asia. It also incorporates changes and issues that gender scholars ought to rethink as the region continue to globalize.

To emphasize a regional perspective, this paper dwells further to the ASEAN4. Composed of Indonesia, Malaysia, Philippines, and Thailand, the ASEAN4 is characterized as a group of developing countries having broadly similar levels of progress while sharing many structural and institutional features (Isnawangsih, Klyuev, \& Zhang, 2013; Siddique, 2011). The key commonalities within the ASEAN4 include: (1) increase in educational opportunities hence equity in the enrollment rates since the 1950's (Booth, 2016); (2) drive towards agricultural diversification since the 1990s which was motivated by the global economic condition's influence on state policies (Taylor, 1994); and (3) drastic labor migration pattern since the mid-1980's to 1990's wherein women working abroad as domestic helpers outnumber men who work in industrial jobs (Rao, 2011; Resurreccion, 2009).

\section{Results and Discussion}

The results and discussion section below is divided into two parts. First is on the trends brought about by global agrarian changes and second is on why it is important to look at Southeast Asia's intersecting gender, family, and agricultural relations. The trends include labor and distress migration, scientific and technological innovations (STIs), and intensification of non-traditional agricultural exports (NTAEs). Following this, I draw attention to current scholarship in the ASEAN region and encourage its exploration in the context of sociology of gender and family.

\section{Global agrarian changes}

Humans of the pre-agriculture world existed for 2,000,000,000 years through hunting and gathering (Bellwood, (2005); Engels (1902); and Lee \& De Vore (1987). There was no strict division of labor but it should be noted that women provided a large share of food as gatherer and men hunted for animals most of the time; this went on until the agriculture period gave way to the emergence of private property which led to the sexual segregation of domestic and public spheres (Engels, 1884; Mies, 1986).

In the process of transitioning, agriculture became part of the public which is dominated by men. By the 1800s, agricultural revolution occurred in relation to industrial revolution. This was reflected in the rise of monocropping and plantations in the selected colonies. In the 1930s, green revolution occurred and was followed by gene revolution in 1990s. Briefly, Green Revolution is the quantum leap for food production from small-scale to largescale which is concentrated on rice, wheat, maize, cassava, and beans (IFPRI, 2002). It was extended to Gene Revolution, which is the application of bio-technology and gene modification in agriculture. At present, agriculture can be characterized as under a modern capitalist system of production. More details about these developments will be elaborated in this section. 


\section{Labor and distress migration}

One of the most discussed trends when it comes to global agrarian changes is labor and distress migration. The International Organization for Migration (2015) refers to labor migration as the "movement of persons from one state to another, or within their own country of residence, for the purpose of employment." The variations include rural-urban, rural-rural, urban-rural, incountry and international, and permanent and cyclical (Borras, 2009). On the other hand, distress migration is defined as the "movement from usual place of residence, undertaken when the individual and/or the family perceive that there are no options open to them to survive with dignity" (Food and Agriculture Organization, 2016). Labor migration is seen as a result of industrialization where rural men's labor in particular became in demand for urban jobs (Boserup, 1970) while distress migration emerged as poverty became increasingly felt by families in the countryside due to several factors like food insecurity (Food and Agriculture Organization, 2016), land grabbing (Thomson, 2014), and climate change (McLeman, 2017).

Labor and distress migrations have been affecting the global agrarian landscape in opposing ways as both cause growth on the part of non-agricultural sector by serving as human resource to factory-based and laborintensive jobs in cities; but also reinforce support to large-scale agro-export type of agriculture through working in private or transnationally-owned plantations. The latter is in the context of rural-urban migration whilst the former is in the ruralrural migration setting. However, in both cases, there is a general common outcome: it has left the farming families of the sending country and specific villages labor deficit but relatively cash rich (Rigg et al., 2016).
In South India, Arun (2012) explored how rural women have been challenging social hierarchies of caste and class in the context of male migration and livelihood diversification. Based on the study, women have become the household head in family farms and they supervise and make decisions on cropping patters, land use, and sales. Govind (2009) points out that in the Maharashtra region, $57.7 \%$ of women farmers work as agricultural laborers outside their home. The daily earnings for women range from 35-38 Rupees while men range from 45-50 Rupees. The situation is different but the role of gender is similarly visible for women who stay in their community to look after their farm. In a research done in China by Eaton \& Shepherd (2001), it was revealed that men are favored by companies when it comes to contract dealings because they have more land rights and family authority. Women whose husbands are away for non-farm works are having difficulty in proposing and closing deals even if they are knowledgeable about it.

\section{Scientific and Technological Innovations (STIs)}

Large-scale production promotes the maximization of STI application in farming. STIs in this context refers to the usage of fertilizers, pesticides (covering herbicides, fungicide, and insecticide), nutrition and breeding management in livestock, and high yielding variety (HYV) seeds also called miracle seeds; and specially the mechanization of harvesting and irrigation processes to have more outputs and in effect income. It is attributed to the Green Revolution although it does not include all agricultural communities evenly (Freed \& Freed, 2002). On the other hand, Gene Revolution occurred as agricultural innovation shifted from the hands of the state to the private sector. It focuses on 
genetic engineering of seeds and intellectual property rights on modified crops by multinational corporations (Prabhu \& Terri, 2007). These genetically modified (GM) products in agriculture which are mostly from the United States, Japan, and European countries are being produced in developing countries such as Argentina, China, Mexico, South Africa, and Uruguay (Davies, 2003).

STIs such as HYV seeds and GM products have been instrumental in transforming the global agricultural practices from subsistence to commercial oriented farming. Consequently, exposure of men and women farmers to various chemicals such as pesticides and herbicides also increase. However, research about the health effects of pesticides have only been largely done on men (Ndlovu et al., 2014) due to the idea that only men do all physical tasks that makes use of chemicals (Rengam, 2007). This is proven otherwise in a study by Saleh, Amr, Jillson, \& Wang (2014) in two villages in Egypt. They noted that more women use pesticides that contain aflatoxin B1 which causes hepatitis C and these women are not aware of the effects of pesticide use in their health.

\section{Intensification of Non-Traditional Agricultural Exports (NTAEs)}

NTAEs refer to products that are not traditionally planted or consumed in a region or country (Robbins, 2007). The intense promotion of NTAEs by transnational agribusiness and export firms on developing countries has influenced the global agrarian setting since the 1980s. Most of these products: seasonal tropical fruits, vegetables, and fresh flowers, are exported by developing countries and imported by the developed ones. Barham, Clark, Katz, \& Schurman (1992) categorize the emergence of NTAEs into three as suggested by David Kaimowitz. First is the farming of any product that has never been in a particular country before, second is the conversion of products for domestic consumption towards export, and third is the development of a new market demand (in the receiving country) for a traditional product (from the exporting country). The impact is seen in country level as the market is outside and the implementation is due to the pressures from aid and lending agencies that aims to elevate poverty in underdeveloped regions (Barham et al., 1992; Rosset, 1991).

In a domestic level, the use of pesticides and fertilizers boomed as seeds of NTAEs needed to be modified according to the temperature/season and environment of the producing country (Food and Agriculture Organization, 2004; Murray \& Hoppin, 1992). While aid is provided by institutions such as World Bank (WB), International Monetary Fund (IMF), and US Agency for International Development (USAID) to the farmers who are willing to convert their subsistence farms to export crops, issues on long term development and sustainability, together with institutional support from local government still arise. NTAEs have unstable prices and saturated markets because of the seasonal character of the products. Additionally, as more developing countries export the same products, its global demand and pricing decrease. One of the changes in the farming community brought by NTAEs is the conversion of members from family labor to hired labor. The mechanisms behind this can be generally seen in two connected ways: first is that NTAEs agribusinesses and firms offer and promote non-traditional work opportunities to subsistence farmers, and second is that the subsistence farmers accept the waged labor offers because they can no longer afford the seeds and other inputs needed for the NTAEs production in their own farm.

Studies by Ferm (2008) and Kay (2002) reveal how the growing NTAEs in Peru, Columbia, Chile, Mexico, and Brazil provide 
employment for women from rural families who have no access to waged work. Majority of the workers in Peru and Columbia's asparagus fields and rose greenhouses are women. The condition is the same in Chile, Mexico, and Brazil where almost 50-65\% of workers in fruit production, vegetable industry, and vineyards are women. It is important to note that while the production is dominated by women, the permanent jobs are usually assigned to men (Deere, 2005). Flexible labor force in this context is distinctly referred to women who are hired in seasonal, temporary, or casual terms. Agribusiness seeks this kind of labor that can work long hours in several months of the year for the lowest possible wage and without any health insurances (Deere, 2005; Lastarria-Cornhiel, 2008). Additionally, there are also studies showing how women whose husbands are migrant workers, experience surveillance from neighbors which in effect limits their activities and movements (Radel et al., 2012).

\section{The women farmers of Southeast Asia}

Feminization of agriculture is broadly defined as the phenomenon of increasing participation of women in the agricultural labor force after the period of industrialization (Boserup, 1970; Lastarria-Cornhiel, 2008; Sachs, 1996). This is regardless of them being independent producers or unpaid family workers. Women who are involved in agro-export sectors pre and post harvesting processes like preservation, packaging, and market selling are also part of this (Deere, 2005). Feminization of agriculture is regarded as a breakaway of women farmers from the traditional gender division of work in the agriculture sector. This also entails being recognized as the household head, having power to make decisions on the usage of the produced, and to some extent, working outside the home or even the community (Agrawal, Rao, \& Joshi, 2013; Govind, 2009; Radel, Schmook, Mcevoy, Méndez, \& Petrzelka, 2012). Below I discuss specific works based in Southeast Asia and the ways that it can be further reconsidered in scholarly engagements.

\section{Indonesia: Masculinization or feminization?}

Semedi (2012) conducted a study on the masculinization of the farming community, Petungkriono, in Central Java. Masculinization, theopposite of feminization, is the increase in men's participation. He used ethnographic materials from 1984 to 2009 , in observing the socio-cultural changes that show waves of masculinization among Petung male farmers. By focusing on gedhig, the practice of hunting wild pigs, as an arena to express masculinity, and on the rise in the use of motorcycles, which people call "Honda," Semedi showed how Petung male farmers gained economic power in a matrilineal and matrilocal community. The improvements of the roads further increased the function of Hondas hence the expression of masculinity - this is in terms of having to work outside the community and of kin keeping roles which women usually do. It was shown how Petung males' effort to have a say in the household economy gave way to such phenomenon.

On the other hand, the work of Winarto \& Utami (2012) about women's leadership roles in rural families in Java interrogates the role and title of the official "head of the household." They argue that changes and continuities in family systems or practices are due to the decisions, actions, and negotiations within the family. Based on the study, the challenges for rural women include temporary out-migration of men in the community (which means more farm work for the left behind wife on top of childcare and housework), state's 
program of releasing identification card for household members (which identifies the husband as default household head), and strong ibuism (motherhood) ideology that the Javanese culture has. The key interviews showed however that rural women's role in the family is gradually changing towards their empowerment. Women negotiate the roles with their husbands and it gets accommodated as the latter acknowledges the importance of developing the skills and talents of the former.

What do these two contradicting cases present us? Theoretical underpinnings regarding research particularity and specificity versus generalizability should be acknowledged. While masculinization was found in Central Java, this case does not negate the fact that feminization has been the large-scale trend. This is because of the specific socio-economic and cultural factors in the former's case while the latter has been largely happening in other regions too. The cases demonstrate that local particulars may not always conform to global trends.

\section{Malaysia: Malay peasant women and the engendered resistance}

The book Malay peasant women and the land by Stivens, Ng, S, \& Bee (1994) discusses Malay women's land rights and providing policy proposal for the government. They suggest that specific dynamics about inheritance and gender ideologies be included in studying agrarian changes in Malaysia. Two of the key themes discuss how land tenure in Semanggol and Pulau Tawar subordinate female labor and how British colonizers changed the Negeri Semibilan's matrilineal property relations. Towards the end, the authors noted how the patriarchal order in village life has been influenced by religious and bureaucratic ideologies. There is also a reminder on how future studies on Malay peasant be placed in the context of
Malay culture, specifically on the family and societal level.

Hart (1991) showed how gender and class analysis intersect with community and household processes using James Scott's Weapons of the Weak.

Based on the study, differences in the forms of resistance taken by rural men and women can be rooted in the politics of production. It is claimed that as men are more engaged in patronage politics so in effect, blatant and collective resistance become difficult for them; while women who are excluded in such politics, are more expressive in collectively challenging the land owners. The history and trajectories of gender relations within labor arrangements in the Muda region was presented to support this. Hart then discussed how official state ideology responded to women's resistance by using Islam ideology that women's rightful position is in the home. Despite this, rural women's resistance continued and their bargaining power increased as demand for agricultural laborers in the 1980s boosted. The gender-informed analysis shown in the work called for the rethinking of concepts on peasant resistance.

Institutional mechanisms through religion and state; and interpretation on engendered resistance that influence farming families are both present in the cases from Malaysia. It is vital to point out how these cases give importance to the historical aspect of societies, especially how antagonizing patriarchal relations were developed and maintained in a former matrilineal community. Consequently, history of the emergence of women's resistance was also put into context as global movements for land and women's rights emerged in the 1980s. As institutions that promote gender and development became more active in forwarding equal rights and access to agricultural sector, women farmers 
also recognized the power of their collective movements.

\section{Philippines: The role of migration and organizations in deconstructing family roles}

Lukasiewicz's (2011) study focuses on wives left behind by migrant husbands in rural families. He posits that new divisions of labor and responsibility are slowly eroding traditional gender ideologies in rural Philippines. Using narratives of women from Lucban Quezon Province who have taken over the management of family farms, he showed the role of migration in the understanding of masculinity and femininity. Decision making processes on land purchasing and household expenditures were revealed as something that left behind wives negotiate and contest to their husbands. Despite this, Lukasiewicz suggests that further critical inquiry on the negotiation processes be done to strengthen the arguments about women's increased agency in the household. The point to reiterate for the said study is that labor migration plays a role in rural families' agrarian expansion.

By using poststructuralist and postcolonial theories, Angeles \& Hill (2009) analyzed the roles of state and nongovernment organizations (NGOs) in reproducing gender differences, hierarchies, roles, and identities. The fieldwork areas for the ethnographic study are Naga City in Bicol and Valencia in Bukidnon. The authors argue that gender analysis must be incorporated in studying agrarian transitions because (1) state policies are gendered, (2) people's livelihood are shaped by gender identities, and (3) agrarian changes also bring changes in gender relations and identities.

Based on the data presented, the livelihood and development policies in both provinces fall on the "male provider" perspective which caters to the needs of men to improve agricultural produce. To add to this, NGOs are also institutionalizing the problematic feminine perceptions within the two provinces as they popularize women-only trainings, like accounting and organization building, because of the belief that women are good at managing money and people. It was revealed at the end that while the state and NGOs encourage women to participate in the agriculture sector, the essentialization of women as mothers, housewives, and secondary breadwinners of the family bring anxiety and work burden.

In terms of studying women's lives, understanding the concept of agency and multiplicity of identities of women were the main points provided by the cases from Philippines. Negotiations between husband and wife are made possible as women recognize their significant role in running the family and the sustaining the farm. Women's agencies in this sense is acknowledged by the men in the family and it reechoes to the community. On the other hand, role strain is experienced by rural women as they are pressured to fit in the multiple identities which are ironically reinforced by NGOs that aim to empower them. The variations in understanding of women empowerment is being raised because such cases reveal that different institutions, whether statesponsored or private, tend to feed their development frameworks on women without understanding their grounded realities.

\section{Thailand: Intra-household relations and feminization of farming villagers}

The 25-year study in two villages (Ban Non Tae and Ban Tha Song) in Thailand by Rigg, Salamanca, \& Parnwell (2012) traced three processes on agrarian change: delocalization of living as level of mobility increase, disembedding of households and families as relations are stretched across 
space, and dissociation of village-community as interests of members diverge. The study discusses how usage of family and household in development processes must be clarified may it be as a unit of analysis or as a concept. The complexity of household relations was pointed out as female headship (of widows and of women with migrant husbands) and co-residence of grandparents and left behind children increased in both villages. This also goes with the authors' call for further analysis on the apparent generational divide between villagers aged 45 and below (who work outside the village) and aged 46 and above (who stay to remain farmers).

Yuki (2012) argues that the feminization of agricultural wage labor is a result of trade liberalization. Using anthropological methods in Dong Pa Sak village in Chiang Mai, Yuki showed how garlic production is a largely feminine sphere in two levels: physical feminization and symbolic feminization. The former refers to the increased presence of women as agricultural laborers for garlic while the latter raises the issue of exploitation of women's labor. Thai garlic growers need to compete with Chinese garlic growers in terms of production so they pay women under the piece-work system which means that the faster and more garlic they process, they more payment will be received. Because garlic production can be done at home, children who are old enough to follow instructions are being asked to assist. The garlic market continues to exist at the expense of women and in a very competitive situation.

The first case from Thailand highlights the role of rigorous research methods that extends in long period and of clarifying the usage of exchangeable terms and unit of analysis like family and household. Their point even goes as far as studying gender with regard to generation. More so, the second case stresses how studies on gender and agriculture can be done in conceptual and empirical level. Both studies showed how the unremunerated labor of children (to process garlic at home) and extended families (to take care of children with both migrant parents) are often ignored in studies about agricultural changes and household dynamics.

\section{Conclusion}

In analyzing the conditions and changing environment of women farmers, developmentallens is useful but a sociological one can reveal more detailed and usually unnoticed elements. The body of literature reviewed here attempt to open and re-open sociological ways in studying agriculture in Southeast Asia.

First, there is a need to further question why and how the "farmer" is continuously equated to man even if a huge amount of literature has already debunked it. Some of the reasons for this misconception include the automatic designation of men as household head hence land owner and the rigid limitation on women's mobility due to religious beliefs which in effect prohibits women to do farm work beyond the family's farm (Agarwal, 2016; Hart, Turton, \& White, 1989). Women can be considered as the first farmers because they were the ones who were more knowledgeable of the plant varieties and processes such as for preservation and for medication. If early farming has always been feminized, it would be worth it to theorize how the feminized farm work experienced de-feminization during the transition to agriculture and now experiencing what we can call re-feminization or reclaiming in the modern capitalist system of agricultural production. This also entails providing variations on the usage of feminization based on historical development or background of the field being discussed; examples are feminization of migration and feminization of poverty. 
Second, in terms of gender relations, there is a need for a more nuanced understanding in the Southeast Asian context because of the region's complex traditions and practices (Akter et al., 2017; Booth, 2016; Gregorio, 2019) where women are traditionally assumed to have "higher status" than men and their roles in agricultural production are more valued compared with women from other Asian regions (Ehrenberg, 1989; Watson Andaya, 1995). Some of the most important factors to see in Southeast Asia are the bilateral and matrilineal kinship systems (Devasahayam, 2009) and women's control on sexuality and fertility, especially during pre-colonial period. Other considerations that can be followed in studying the Southeast Asian context are "historical processes such as colonialism, nationalism, encounters with the West, state building, and middle-class formation" (Hayami \& Tamura, 2012, p. 18).

Third, in studying agrarian development in ASEAN4 vis-à-vis family relations, Hart et al. (1989), suggested that one direction is to explore the links between gender and generation as factors. This point also surfaced in Thompson's (2007) ethnographic work about urbanism in rural Malaysia where the age and gender demographic structure, which shows that young male adults (age 20-40) constitute the smallest age set, which affects the production work in the farms and social practices in the families and community. Different family forms in Southeast Asia such as commuter couples who travel and rent a space for their work and return home in weekly or monthly basis as show in Gregorio's (2020a, 2020 b) works should also be explored. For more discussion on possible theoretical openings on family and generational roles in smallholding agriculture, see the edited volume of Thompson and colleagues (2019).

Fourth, while agrarian reforms can lead to equitable land ownership or distribution, it can also cause loss of land and livelihood through allowing monopoly or corporate ownership (IBON Institute for International Development, 2014; Jacobs, 2010). Given this situation, Razavi (2009) posits that advocates of gender equality and women empowerment have to put into question the ambiguous position of the local state in facilitating agricultural reforms. The local state's position then can be described as being in close to the community organizations and the families, but most of the time on male members who are part of local organization and are active in policy dialogues. While political participation of individual women in institutional levels have long been studied (Agarwal, 2016; Bock \& Shortall, 2006; Heyzer, 1987; Jacobs, 2010), the partnership between women-based agricultural NGOs and the local state is barely discussed.

With the abovementioned points, it is then recommended that more sociological research about women farmers be conducted, in a regional and comparative outlook. Concerning issues on methodology, the important role of grounded ethnographic work in analyzing gender relations and agrarian changes in specific and general cases must be recognized. This method helps greatly in identifying and understanding the factors (technology, cultural and economic changes) that brought the local conditions to modify, affirm, or sometimes negate global trends. It is also recommended that in studying women farmers, sociologists continue to interrogate the role of the home and various family relations where gender division of work is still strongly visible. By looking at the micro-relations inside Southeast Asian households, more can be discovered about the existence, absence, or reconfiguration of gender roles, age-based hierarchies, and other internal decisionmaking processes that impact women and their families. 


\section{Declaration of Ownership}

This article is my original work.

\section{Conflict of Interest}

There is no conflict of interest to declare in this article.

\section{Ethical Clearance}

This study was approved by the institution.

\section{References}

Agarwal, B. (2016). Gender challenges. Oxford University Press.

Agrawal, R., Rao, D. R., \& Joshi, G. P. (2013). Feminisation of Indian Agriculture: Issues and challenges. Madhya Pradesh Journal of Social Sciences, 18(1), 27.

Akter, S., Rutsaert, P., Luis, J., Htwe, N. M., San, S. S., Raharjo, B., \& Pustika, A. (2017). Women's empowerment and gender equity in agriculture: A different perspective from Southeast Asia. Food Policy, 69, 270-279. https://doi. org/10.1016/j.foodpol.2017.05.003

Angeles, L. C., \& Hill, K. (2009). The gender dimension of the agrarian transition: Women, men and livelihood diversification in two peri-urban farming communities in the Philippines. Gender, Place $\mathcal{E}$ Culture, 16(5), 609. https://doi. org/10.1080/09663690903148465

Arun, S. (2012). 'We are farmers too': Agrarian change and gendered livelihoods in Kerala, South India. Journal of Gender Studies, 21(3), 271-284. https://doi.org/10. 1080/09589236.2012.691650

ASEAN Trade Statistics Database. (2015). ASEAN statistical yearbook 2014. ASEAN Trade Statistics Database.
Barham, B., Clark, M., Katz, E., \& Schurman, R. (1992). Nontraditional agricultural exports in Latin America. Latin American Research Review, 27(2), 43-82.

Bellwood, P.S. (2005). First farmers. Blackwell.

Bhandari, A. (2017). Women's status and global food security: An overview. Sociology Compass, 11(5), e12479. https:// doi.org/10.1111/soc4.12479

Bock, B. B., \& Shortall, S. (2006). Rural gender relations: Issues and case studies (1st ed.). CABI Publishing.

Booth, A. (2016). Women, work and the family: Is Southeast Asia different? Economic History of Developing Regions, 31(1), 167-197. https://doi.org/10.1080/20 780389.2015.1132624

Borras, S. M. (2009). Agrarian change and peasant studies: Changes, continuities and challenges - an introduction. The Journal of Peasant Studies, 36(1), 5. https:// doi.org/10.1080/03066150902820297

Boserup, E. (1970). Woman's role in economic development. St. Martin's Press.

Chauhan, K. (2014). Gender and development. In K. Chauhan, Gender inequality in the public sector in Pakistan (pp. 13-39). Palgrave Macmillan US. https://doi.org/10.1057/9781137426475_2

Davies, W. P. (2003). An historical perspective from the green revolution to the gene revolution. Nutrition Reviews, 61, S124S134. https://doi.org/10.1301/nr.2003.jun. S124-S134

Deere, C. D. (2005). The Feminization of agriculture? Economic restructuring in rural Latin America (p. 66) [Occasional Paper \#1]. United Nations Research Institute for Social Development (UNRISD).

Devasahayam, T. W. (2009). Introduction: Women in Southeast Asia. In Gender trends in Southeast Asia: Women now, women in the future (pp.1-11). Institute of Southeast Asian Studies. 
Eaton, C., \& Shepherd, A. W. (2001). Contract farming (Vol. 145). Food and Agriculture Organization of the United Nations.

Ehrenberg, M. (1989). Women and pre-history. British Museum.

Engels, F. (1884). The origin of the family, private property, and the state. Charles $\mathrm{H}$. Kerr \& Co.

Ferm, N. (2008). Non-traditional agricultural export industries: Conditions for women workers in Colombia and Peru. Gender $\mathcal{E}$ Development, 16(1), 13. https://doi. org/10.1080/13552070701876078

Food and Agriculture Organization. (2004). The market for non-traditional agricultural exports. IOM and Labour Migration.

Food and Agriculture Organization. (2016). Distress migration and youth in protracted crises (p. 21). FAO. http://www.fao.org/3/ a-i6632e.pdf

Freed, S., \& Freed, R. (2002). Green revolution: Agricultural and social change in a north Indian village. American Museum of Natural History.

Govind, K. (2009). The Feminization of agriculture in Asia: Implications for women's agency and productivity (p. 16). UNIFEM South-Asia Regional Office. http://www.fftc.agnet.org/htmlarea_file/ library/20110725164020/eb594.pdf

Gregorio, V. L. (2019). Farming families in Malaysia and the Philippines: Empirical works and classical debates. Asia-Pacific Social Science Review, 19(2), 47-62.

Gregorio, V. L. (2020a). Farm and familialism in Southeast Asia: Gender and generational relations in Malaysian and Philippine villages [PhD Thesis]. National University of Singapore.

Gregorio, V. L. (2020b). Isolation and immunity within the family: Commuter marriages in Southeast Asia. Current Sociology. https://doi. org/10.1177/0011392120972143
Hart, G. (1991). Engendering everyday resistance: Gender, patronage and production politics in rural Malaysia. The Journal of Peasant Studies, 19(1), 93.

Hart, G. P., Turton, A., \& White, B. (1989). Agrarian transformations: Local processes and the state in Southeast Asia. University of California Press.

Hayami, Y., \& Tamura, K. (2012). The family in flux in Southeast Asia. Kyoto University Press.

Heyzer, N. (1987). Women farmers and rural change in Asia. Asian and Pacific Development Centre.

IBONInstitutefor InternationalDevelopment. (2014). Neoliberal subversion of agrarian reform. IBON International.

IFPRI. (2002). Green revolution: Curse or blessing? International Food Policy Research Institute.

International Organization for Migration. (2015, January 14). Key migration terms. International Organization for Migration. https://www.iom.int/key-migrationterms

Jacobs, S. M. (2010). Gender and agrarian reforms: Vol. 9. Routledge.

Kay, C. (2002). Chile's neoliberal agrarian transformation and the peasantry. Journal of Agrarian Change, 2(4), 464-501. https:// doi.org/10.1111/1471- 0366.00043

Lastarria-Cornhiel, S. (2008). Feminization of agriculture: Trends and driving forces. Washington, DC: World Bank.

Lee, R. B., \& De Vore, I. (Eds.). (1987). Man the hunter (11. Print). de Gruyter.

Lukasiewicz, A. (2011). Migration and gender identity in the rural Philippines. Critical Asian Studies, 43(4), 577-593. https://doi. org/10.1080/14672715.2011.623523

McLeman, R. (2017). Migration and land degradation: Recent experience and future trends. United Nations. 
Mies, M. (1986). Patriarchy and accumulation on a world scale. Zed Books.

Momsen, J. H., \& Kinnaird, V. (1993). Different places, different voices. Routledge.

Murray, D. L., \& Hoppin, P. (1992). Recurring contradictions in agrarian development: Pesticide problems in Caribbean basin nontraditional agriculture. World Development, 20(4), 597-608. https://doi. org/10.1016/0305-750X(92)90047-Y

Ndlovu, V., Dalvie, M. A., \& Jeebhay, M. F. (2014). Asthma associated with pesticide exposure among women in rural Western Cape of South Africa: Asthma and pesticides among rural South African Women. American Journal of Industrial Medicine, 57(12), 1331-1343. https://doi. org/10.1002/ajim.22384

Nontraditional Agricultural Exports (NTAEs). (2007). In Encyclopedia of environment and society. SAGE Publications, Inc. https://doi. org/10.4135/9781412953924.n778

Prabhu, P., \& Terri, R. (2007). Asian agricultural development: From the green revolution to the gene revolution. In A. Balicasan \& N. Fuwa (Eds.), Reasserting the rural development agenda: Lessons learned and emerging challenges in Asia (pp. 179-210). Institute of Southeast Asian Studies.

Quisumbing, M. A. R., Meinzen-Dick, R. S., Raney, T. L., \& Croppenstedt, A. (2014). Gender in agriculture. Springer.

Radel, C., Schmook, B., Mcevoy, J., Méndez, C., \& Petrzelka, P. (2012). Labour migration and gendered agricultural relations: The feminization of agriculture in the Ejidal Sector of Calakmul, Mexico. Journal of Agrarian Change, 12(1), 98$119 . \quad$ https://doi.org/10.1111/j.14710366.2011.00336.x

Rathgeber, E. M. (1990). WID, WAD, GAD: Trends in research and practice. The Journal of Developing Areas, 24(4), 489-502.
Rengam, S. V. (2007). Resisting poisons, reclaiming lives: Impact of pesticides on women's health. Pesticide Action Network Asia and the Pacific (PAN AP).

Rigg, J., Salamanca, A., \& Parnwell, M. (2012). Joining the dots of agrarian change in Asia: A 25 Year View from Thailand. World Development, 40(7), 1469-1481. https://doi.org/10.1016/j. worlddev.2012.03.001

Rigg, J., Salamanca, A., \& Thompson, E. C. (2016). The puzzle of East and Southeast Asia's persistent smallholder. Journal of Rural Studies, 43, 118-133. https://doi. org/10.1016/j.jrurstud.2015.11.003

Rosset, P. M. (1991). Sustainability, economies of scale, and social instability: Achilles heel of non-traditional export agriculture? Agriculture and Human Values; Journal of the Agriculture, Food and Human Values Society, 8(4), 30.

Sachs, C. E. (1996). Gendered fields. Westview Press.

Saleh, D. A., Amr, S., Jillson, I. A., \& Wang, J. H. (2014). Knowledge and perceptions of hepatitis $C$ infection and pesticides use in two rural villages in Egypt. BMC Public Health, 14, 501.

Semedi, P. (2012). Masculinization of a Javanese farming community's household economy: Petungkriono, 1984-2009. In J. Rigg \& P. Vandergeest (Eds.), Revisiting rural places: Pathways to poverty and prosperity in Southeast Asia (pp. 179-192). NUS Press.

Stivens, M., Ng, C., Sundaram, J., \& Bee, J. (1994). Malay peasant women and the land. Zed Books.

Thompson, E. C. (2007). Unsettling absences: Urbanism in Rural Malaysia. NUS Press.

Thompson, E.C.(2015). Ruraltransformations. In M. L. Weiss (Ed.), Routledge handbook of contemporary Malaysia (pp. 236-248). Routledge. 
Thompson, E. C., Rigg, J., \& Gillen, J. (Eds.). (2019). Asian smallholders in comparative perspective. Amsterdam University Press.

Thomson, F. (2014). Why we need the concept of land-grab-induced displacement. Journal of Internal Displacement, 4(2), 4265.

Watson Andaya, B. (1995). Women and economic change: The pepper trade in pre-modern Southeast Asia. Journal of the Economic and Social History of the Orient, 38(2), 165-190. https://doi. org/10.1163/1568520952600579
Winarto, Y., \& Utami, S. P. B. (2012). Women's empowerment in persisting and changing 'family' norms in Java. In Y. Hayami \& T. K. T (Eds.), The family in flux in Southeast Asia (pp. 275-294). Kyoto University Press.

Yuki, M. (2012). The complexity of feminization of garlic production in the era of trade liberalization in Northern Thailand. Gender, Technology and Development, 16(3), 279-298. https://doi. org/10.1177/0971852412459426 